\title{
Formar e assistir: imagens da escola do Senai em Curitiba nas décadas de 1940 e 1950
}

\author{
Training and providing assistance: images of \\ Curitiba's Senai school in the 1940s and 1950s
}

Vera Regina Beltrão
Marques

Professora de História da Educação no Setor de Educação/Universidade Federal do Paraná.

Rua Gal. Carneiro, 460/403

80060-150 - Curitiba - PR - Brasil

verarbm@terra.com.br

\section{DesirêLuciane \\ Dominschek}

Professora de História da Educação no curso de Pedagogia/Faculdade Internacional de Curitiba. desiredominschek@grupouninter. com.br

Rua Albina Reffo Bochino, 2

82900-260 - Curitiba - PR - Brasil
MARQUES, Vera Regina Beltrão; DOMINSCHEK, Desirê Luciane. Formar e assistir: imagens da escola Senai em Curitiba nas décadas de 1940 e 1950. História, Ciências, Saúde - Manguinhos, Rio de Janeiro, v.18, supl.1, dez. 2011, p.275-293.

\section{Resumo}

O Serviço Nacional de Aprendizagem Industrial (Senai) foi instalado no Paraná em 1943, objetivando capacitar força de trabalho para a indústria. Por meio de imagens e documentos escritos, guardados na Federação das Indústrias do Estado do Paraná, apresentam-se aspectos da formação para o trabal ho na escola do Senai de Curitiba, tanto na perspectiva institucional quanto através do discurso dos alunos. Imagens e discursos são aproximados apontando vicissitudes do projeto de formação para o trabalho proposto por essa instituição de cunho privado, que contou com o anteparo público concedido aos industriais para formar trabal hadores, especialmente aprendizes de ofício.

Palavras-chave: imagens; formação para o trabalho; assistência e saúde; Serviço Nacional de Aprendizagem Industrial; Paraná (Brasil).

\section{Abstract}

A branch of the Serviço Nacional de A prendizagem Industrial (Senai) was set up in Paraná in 1943 to train industrial labor. Images and written records held by the Paraná State Federation of Industries depict aspects of technical training at the Senai school in Curitiba, both from an institutional perspective and from the students', through their discourse. A comparison of these images and discourses serves to highlight the vicissitudes of this private institution's vocational training project, which received government support for the instruction of industrial workers, especially apprentices.

Keywords: images; technical training; assistance and health; Serviço Nacional deA prendizagem Industrial ; Paraná (Brazil). 
Vera Regina Beltrão Marques, Desirê Luciane Dominschek

A utilização de imagens fotográficas por historiadores vem permitindo realizar trabal hos renovadores no âmbito da história, seja da educação, da saúde ou da ciência. Entendendo que cada momento histórico produz representações passíveis de serem analisadas pelo historiador eque podem propiciar outras versões da temática à historiografia, propomos apresentar a formação de jovens aprendizes por meio de imagens fotográficas na escola do Serviço Nacional de Aprendizagem Industrial (Senai) em Curitiba, nas décadas de 1940 e 1950.

Como outras fontes de pesquisa, a fotografia enseja compreender pelo olhar, permite ana lisar relações, e pode ampliar e enriquecer a variedade de fontes com as quais o historiador trabalha. "Se a imagem acompanha a vida humana como representação da realidade, como memória e expressão da cultura de um povo, de uma época, garantia de uma visão do pas sado, hoje, com a comunicação informatizada, ela nos desafia a compreendêla em novas temporalidades, como mediação complexa dos processos educativos" (Ciavatta, 2002, p. 24).

Utilizamos imagens do acervo composto e guardado na Casa da Memória, localizada na sede da Federação das Indústrias do Estado do Paraná (Fiep), e as confrontamos com fontes escritas (relatórios, boletins, periódicos) e ainda com documentos existentes no Arquivo Edgar Leuenroth e na Biblioteca do Instituto de Filosofia e Ciências Humanas (IFCH), da Unicamp. As imagens são pontuadas pela leitura de documentos provindos do Senai, pela produção de historiadores ou pelo periódico editado pelos alunos.

Clicadas por fotógrafos não identificados e contratados pelo Senai, as fotos apresentam momentos diversos do processo de formação na perspectiva institucional, ou seja, como o Senai queria dar-se a conhecer, difundir-se pelas imagens que divulgava. Trata-se do que Peter Burke (2004) assinalaria como um processo em que artista e modelo experimentavam certa cumplicidade, tornando-se parceiros coniventes.

O princípio que orientou a seleção e apresentação das imagens é conferido pela máxima que norteava os cursos formadores de aprendizes: instrução racional para meninos pobres. Imbuídos do espírito de que 'homens certos nos lugares certos' poderiam render mais e mel hor, privilegiavam conformar corpos higienizados à imagem de máquinas bem azeitadas, para que assim pudessem atender ao processo produtivo que se intensificava nas décadas de 1940 e 1950.

\section{Na terra das araucárias}

No Paraná, o desenvolvimento da indústria teve no mate seu principal produto de exportação, ainda no século XIX (Pereira, 1996). Em 1900, 98\% do valor exportado daí advinha, e a Fábrica de Fundição Marumby, por exemplo, ou a Fábrica de Isaias Alberti, produtora de moinhos, el evadores e serras circulares, além de outras, eram quase subsidiárias do mate. A partir da Primeira Guerra Mundial, o pinho do Paraná passou a ocupar o segundo lugar nos produtos estaduais para exportação, e com o crescimento do mercado interno surgem outras fábricas e pequenas oficinas. Cervejas, alimentos, fósforos, instrumentos musicais, sapatos, louças eram produzidos; olarias, curtumes e pequenas indústrias químicas se faziam notar de tal forma, que em 1920 havia 255 fábricas e oficinas e 3.448 operários (Queluz, 2000). 
O crescimento desordenado de Curitiba, a partir da construção da estrada de ferro e da intensificação da chegada de imigrantes, empurrava a população para locais insalubres, sobretudo cortiços no Centro da cidade, o que propiciava doenças e surtos epidêmicos. Pobres, miseráveis, "perambulando pelas ruas, malcheirosos e famintos" (De Boni, 1998, p.28), atestavam a desordem e caminhavam na contramão da modernidade e da repre sentação de metrópole civilizada, tão caras às elites curitibanas. Ademais, crianças desprovidas e vagando pelas ruas redundariam em adultos de "índole indefinida, mentalidade inconstante, vícios políticos e sociais" (p.131), prontas a qualificar-se nas denominadas classes perigosas; não se tornariam trabalhadores ordeiros e disciplinados, conforme demandava o capital.

Algumas iniciativas buscavam dar conta de disciplinar crianças e jovens no intuito de, por um lado, resolver o problema das classes perigosas e, por outro, formar mão de obra para atividades em expansão na cidade. Desde 1912, a polícia propunha uma escola premunitória: "[para] evitar que perambulem pela via pública pequenos mendigos, que cedo ou tarde penetrarão nas trevas da degradação máxima" - segundo relatório do chefe de polícia (citado em De Boni, 1987, p.92).

O delegado de polícia Moreira Garcez, ao detectar o aumento da criminalidade infantil em Curitiba, entendeu que, sem hábitos de trabalho e instrução, inúmeras crianças se converteriam em legiões de criminosos e competia ao Estado adotar meios de prevenção e repressão. Caberia, de acordo com o relatório de 1917 do chefe de polícia, criar um instituto disciplinar para incutir hábitos de trabalho, "educar e fornecer instrução literária e profissional, essa última de preferência agrícola, aos maiores de 9 anos e menores de 14 que obrarem com discernimento; aos maiores de 14 anos e menores de 21 , condenados por infração do Art.399 do Código penal e Art. 2 do Decreto Federal ..." (citado em Karvat, 1998, p.131).

A inauguração da Escola Agronômica foi saudada com pompa e circunstância. 0 Patronato Agrícola, criado com a Escola, era destinado exclusivamente às classes pobres e visava "à educação moral, cívica, física e profissional de menores despossuídos e daqueles que, por insuficiência da capacidade de educação na família, foram postos, por quem de direito, à disposição da Escola Agronômica". Esse instituto de "assistência, proteção e tutela moral de menores" recorria ao efeito do trabalho agrícola, "sem outro intuito que não o de utilizar sua ação educativa e regeneradora, com o fim de dirigir e orientar, até incorporálos no meio rural" (Karvat, 1998, p.134).

No meio urbano, a Escola de Aprendizes Artífices, criada por decreto federal e referida como casa do trabalho, casa de pequenos operários ou abrigo moral, também ansiava instaurar hábitos de trabal ho nos "desfavorecidos da fortuna", além de ensinar-Ihes al gum ofício, pois, como rezava o decreto 7.566, de 1901, é "o indispensável preparo técnico e intelectual, como fazêlos adquirir hábitos de trabalho profícuo, que os afastará da ociosidade, escola do vício e do crime, [posto] que é dos primeiros deveres do Governo da República formar cidadãos úteis à nação" (citado em Pandini, 2006, p.38).

Logo, moralizar socialmente crianças pauperizadas encaminhando-as para instituições disciplinares e de ensino, na Curitiba moderna do século passado, parece ter sido a fórmula encontrada para tirá-las das ruas. Educá-las implicava incutir-Ihes amor ao trabalho, respeito 
à hierarquia e à ordem, apego à civilização e a todas as máximas apregoadas pela moral burguesa. Ensinar 'disciplinas' - eis o mote das ações pedagógicas.

Ao considerar as escolas Senai em seus começos, na década de 1940, observamos que os aprendizes, também filhos das classes pobres, ali aprendiam 'disciplinas' e mais: o processo formador buscava assegurar as máximas de amor ao trabal ho e de respeito à hierarquia, à ordem. Qual era então a novidade trazida pela escola?

\section{OSenai paranaense}

Instalado no Paraná em 1943, a fim de formar mão de obra qualificada para a indústria, o Senai ${ }^{1}$ esteve inicialmente subordinado à Del egacia Regional do Paraná e Santa Catarina, com sede em Curitiba, pois a industrialização existente não motivava a criação de uma Federação das Indústrias nesses dois estados. Em 1947, essa delegacia foi transformada no Departamento Regional do Senai, Escola Profissional de Curitiba.

Tendo como ideia a organização racional do trabal ho², o Departamento também seguia a proposta nacional de melhor adestrar para a indústria, (re)formar (Weinstein, 2000), conforme os interesses das empresas, adolescentes já empregados, logo, inseridos no sistema de fábrica. Isso porque o aluno, ao mesmo tempo que executava atividades no chão da fábrica, reservava metade da jornada de trabalho para os conteúdos teóricos e práticos (oficinas) que compunham sua aprendizagem na escola. Ao funcionar como centro de formação profissional, seguiam as deliberações exaradas pelos industriais - decorrência de o Estado ter delegado à instituição o direito de "ministrar ensino profissional a aprendizes da indústria, dos transportes, das comunicações e da pesca, bem como ensino de continuação e de aperfeiçoamento a trabal hadores não sujeitos à aprendizagem", como registra o Regimento das Escolas de Aprendizagem do Senai (citado em Fonseca, 1986).

Diferentemente das escolas de aprendizes-marinheiros e de artífices ou de escolas profissionais (masculina e feminina) - instituições mantidas por órgãos públicos -, os centros formadores (escolas) do Senai eram privados, portanto organizados, supervisionados e geridos por entidade de industriais sob a égide da Confederação Nacional das Indústrias. Vale salientar: asilos, reformatórios, institutos e outras instituições dirigidas às crianças desfavorecidas ou pretensamente 'perigosas', ain da que desenvolvessem alguma modal idade de ensino profissional, diferenciavam-se das escolas profissionais cuja maior pretensão residia em formar aprendizes, especialmente os filhos de operários.

Os cursos do Senai, portanto, não podem ser pensados como lócus de assistência a adolescentes desamparados, mas sim como projeto dos industriais para formar mão de obra deacordo com suas expectativas. No decorrer do processo descobriram quesua clientela advinha de famílias pobres, adoecidas, que podiam ser consideradas um problema e necessitavam de assistência para viabilizar a formação requerida, mas tal assistência não constava no projeto original.

Roberto Mange ${ }^{3}$, primeiro diretor do Senai-SP, fez publicar, no Informativo de março de 1946, como entender a educação integral de pequenos operários: conjugando aspectos técnico-profissionais com aqueles educativos esociais; evidenciando que sua ação transcen dia o simples ensino, para assumir uma feição social ao proporcionar serviços de natureza 
"paraescolar no campo da educação, da higiene e da assistência social". "Este conceito obedece a uma tendência moderna de educação visando a formação integral de um 'homem', isto é, uma formação cultural e profissional em torno de uma sadia personal idade" (Senai, mar. 1946, p.3). ${ }^{4}$

Esse entendimento começara a vigorar a partir de pesquisas realizadas pelo Senai-SP, ao buscar caracterizar o alunado e estabelecer seu "retrato psicológico". Os estudos representaram o aluno como "adolescente comum", vivendo sob influências que deformavam sua personalidade, a considerar a "falta de assistência familiar, trabalho desinteressante, má habitação e alimentação, ambientes inadequados, convívio demorado com adultos deseducados, precocidade de responsabilidades", entre outras (Senai, out. 1946, p.4). Tal representação cabia nos diagnósticos de adolescente-problema colocados por Arthur Ramos (1954) na obra A criança-problema, na qual se destaca como as influências da família, da "sociedade e da cultura impregnavam a personalidade, moldando-lhes atitudes e preferências" (p.10).

Convencidos de que essas influências consideradas deformativas poderiam ser combatidas, utilizavam os aportes da higiene - a mental incluída - ofertando-as à escola. $\mathrm{O}$ médico A.C. Pacheco e Silva, por exemplo, mais tarde presidente da Federação das Indústrias de São Paulo (Fiesp), recomendava (re)educar, em vez de reprimir, condutas pouco condizentes com a formação racional de futuros operários. A partir do diagnóstico realizado no Senai-SP, reeducar significou criar uma rede de assistência ao aluno e, depois, aos operários, por meio dos serviços oferecidos pelo Serviço Social da Indústria (Sesi) aos trabalhadores (Weinstein, 2000) - instigante, a se considerar a proposta de formação racional inicial, desprovida de qualquer projeto assistencialista.

Assim, os serviços paraescolares, cuja função era propiciar ao aluno sobretudo al imentação e combate às doenças, caminharam de mãos dadas com a aprendizagem industrial. Era impossível prepará-los para o trabalho desconsiderando os altos coeficientes de infestação por vermes e protozoários, os problemas de visão, a tuberculose frequente, as desinterias, a subnutrição ou a estafa. Moldá-los para as atividades industriais implicava recuperá-los das enfermidades, pois era notório: do estado de saúde física e mental dos trabal hadores dependia o rendimento das indústrias - garantiam os médicos higienistas (Marques, 2009). E afiançar a priori a seleção de alunos hígidos, considerados mais aptos ao batente, se reve lara falacioso desde as primeiras avaliações de saúde, ocorridas no Senai-SP (Senai, 1944). ${ }^{5}$

A novas orientações implicaram uma mudança de premissa para todas as regionais. Valorizar o futuro operário como ser humano e cidadão trabalhador significaria também dar-Ihes de comer e livrá-los das mazelas provocadas pelas moléstias. Logo assistir e curar aprendizes tornou-se fundamental, e um projeto de formação integral de aprendizes se impôs sobre as hostes da ciência racionalizadora, especialmente na era M ange (1942-1955).

Apresentamos imagens desse processo formador em Curitiba dividindo-as em duas partes. A primeira delas, "Aprendizes em formação", é constituída de nove fotos (Figuras 1 a 9) e representam o cotidiano da escola. Nelas aparecem aprendizes em oficinas de diversos cursos; nos momentos em que recebiam visitas, normalmente autoridades; em atividades esportivas e de lazer; e no atendimento em serviços sociais. São imagens que dão a ver o aluno Senai em seu processo de forma(ta)ção para o trabal ho. Embora fora do âmbito da escola de Curitiba, incluímos uma foto de aprendizes mineiros em Siderópolis (SC), em 
um curso que pretendia qual ificar aprendizes para atuar em explorações no subsolo, situação emblemática ao considerarmos a faixa etária dos aprendizes fotografados (entre 14 e 18 anos), quando a lei determinava 21 anos como idade mínima para trabal hos no subsolo.

No segundo grupo, "A formação para o trabalho através do ol har dos alunos", constam sete imagens (Figuras 10 a 16) do acervo fotográfico de 0 Escudo, órgão oficial dos alunos e publicado pela escola de Curitiba. ${ }^{6}$ Nesse periódico os aprendizes manifestavam opiniões sobre a formação proporcionada pela entidade. São mencionadas atividades formadoras que extrapolam as oficinas: solenidades cívicas e religiosas, torneios, viagens; enfim, 'retratam' como os aprendizes dirigentes da associação do alunado se envolviam como partícipes de um projeto a que muitos, mas não todos, aderiram.

Concluímos apontando aspectos que reputamos importantes, nessa empreitada de formação de aprendizes sob os ditames da indústria.

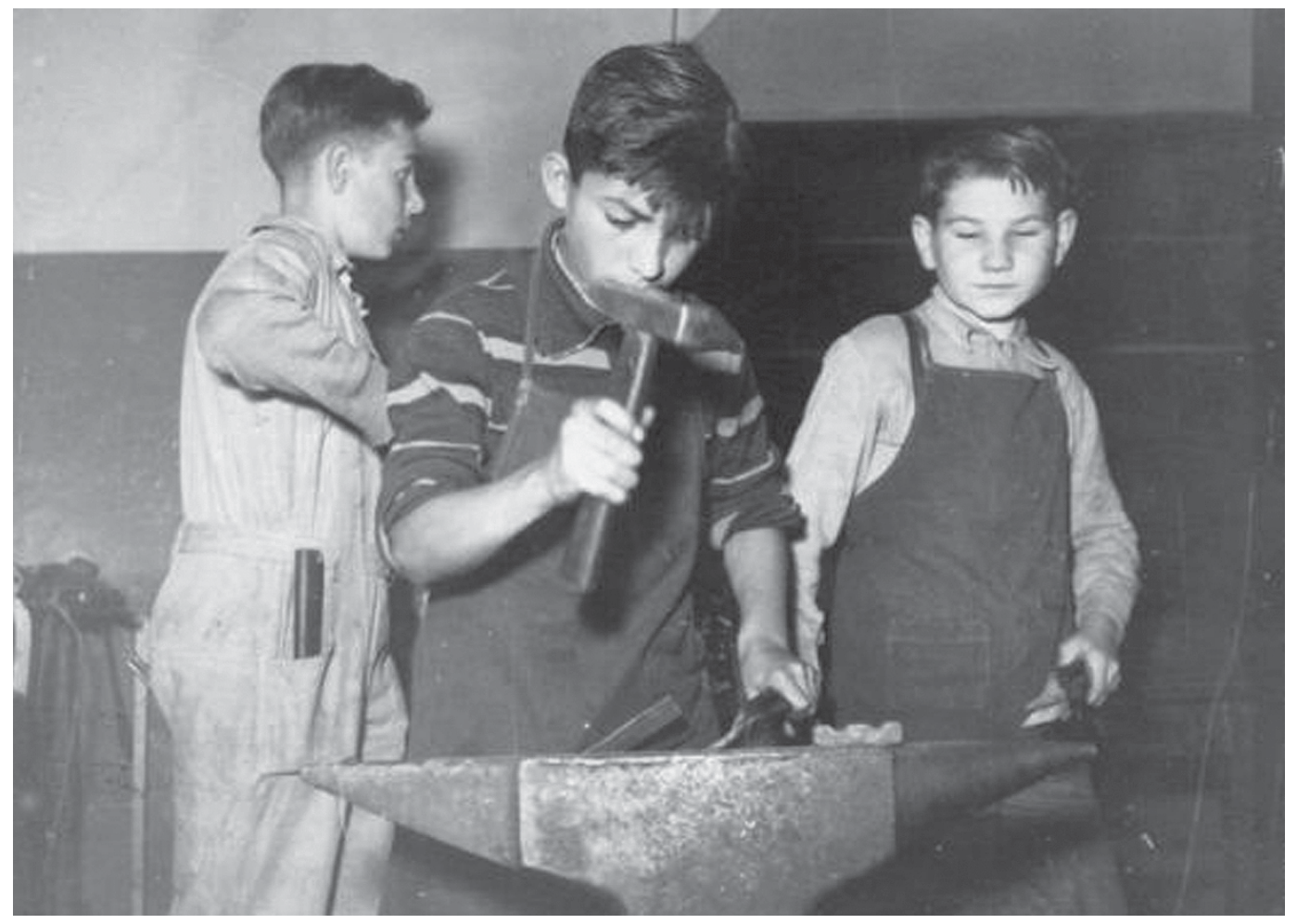

Figura 1: Oficina de ferraria, s.d. Senai-PR (Centro de Memória do Sistema Fiep)

"A nossa finalidade é, sem dúvida, a formação profissional. Para esse fim precisamos de alunos normais e que queiram a escola". A seleção dos al unos era feita considerando-se os aspectos físico, clínico, psíquico e o nível de conhecimentos. Realizavam ainda pesquisas sociais acerca dos educandos. "No intuito de precisar o padrão normal de peso, estatura e índice ponderal dos adolescentes desta Região, foi iniciado um estudo estatístico sobre aqueles dados, em todos os candidatos apresentados para matrícula nas Escolas do Paraná e Santa Catarina" (Senai, 1944-1945). 


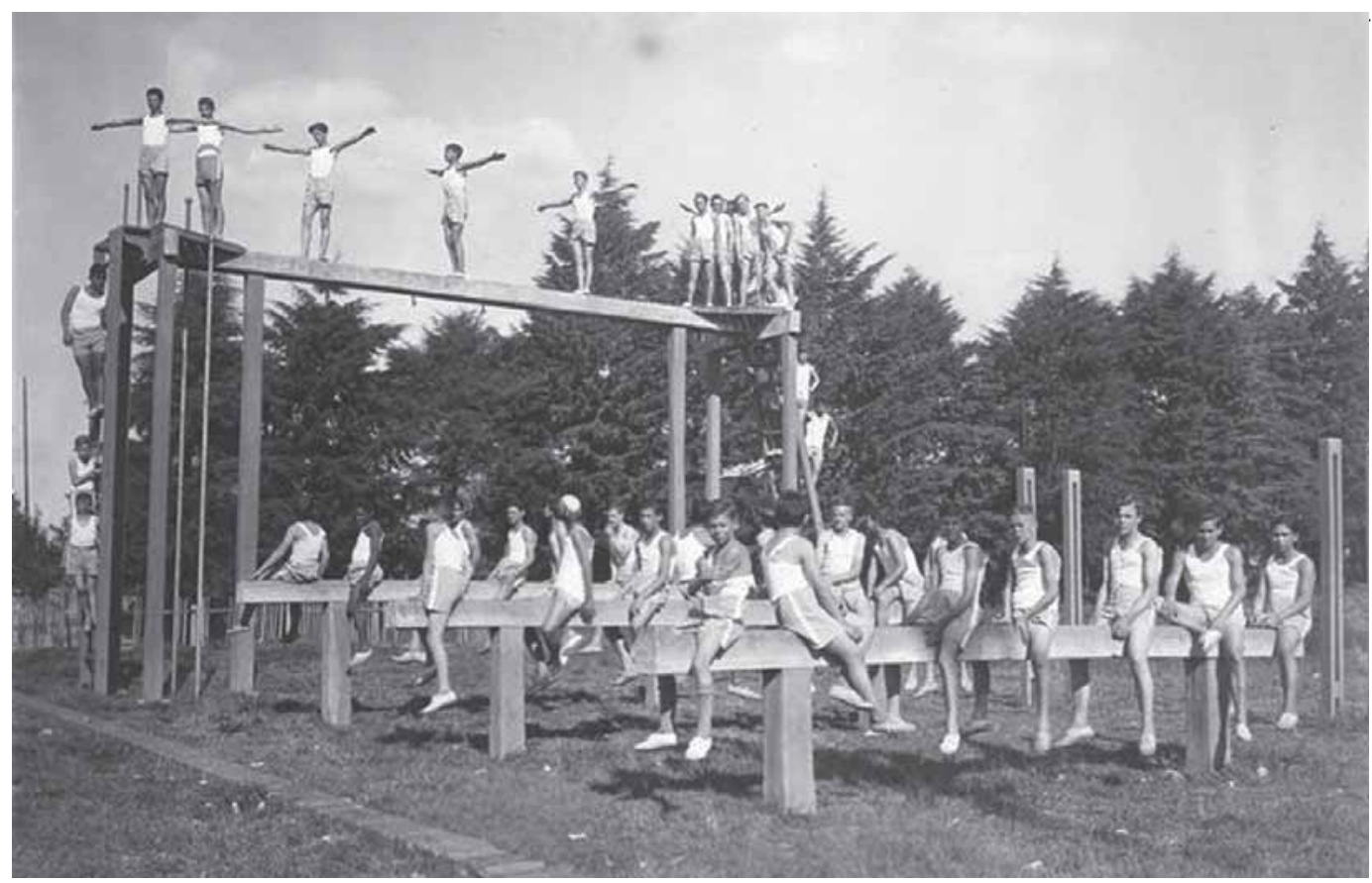

Figura 2: Estádio, 1945. Senai-PR (Centro de Memória do Sistema Fiep)

“Estamos convictos que fazer de cada indivíduo um cidadão prestante pela quantidade e qualidade do seu trabalho éa gran de causa da Nação Brasileira pesando quase inteiramente sobre o nosso sistema educativo. Teremos que, de acordo com Durkheim suscitar e desenvolver nos indivíduos certo número de estados físicos, intelectuais e morais reclamados pelo meio a que o indivíduo se destina". A formação do cidadão operário ocorreria "perfeitamente ajustado à máquina social" (Senai, 1944-1945).

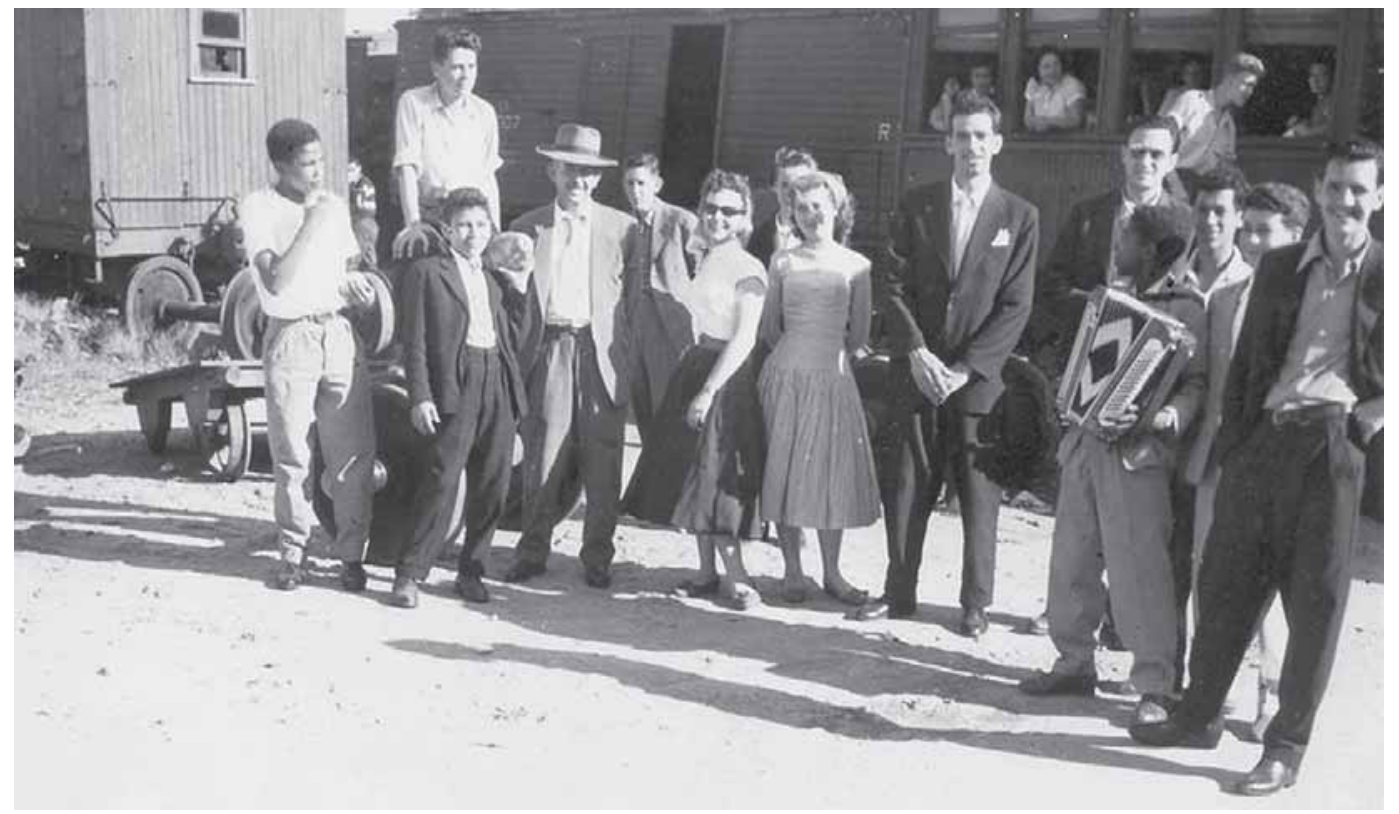

Figura 3: Viagem de professores e alunos, 1945. Senai-PR (Centro de Memória do Sistema Fiep) 
Vera Regina Beltrão Marques, Desirê Luciane Dominschek

"Trazêlos para a escola pelo prazer de frequentá-la, pela necessidade sentida". Para tanto, procuravam satisfazer os interesses dos adolescentes indo além dos conteúdos técnicos. Esportes, torneios, olimpíadas e excursões tinham lugar de destaque nesse universo formador. Ademais, a evasão mostrou-se muito elevada nos primeiros anos de atuação da escola, e alunos com alguma formação encontravam postos de trabalho em oficinas e fábricas curitibanas. Também foram registradas muitas faltas por doença. Tentar mantê-los nos cursos ofertados foi um desafio a mais, pois no primeiro semestre de 1943 a evasão foi de 51\% nos cursos de aprendizes operários (Senai, 1943-1947).

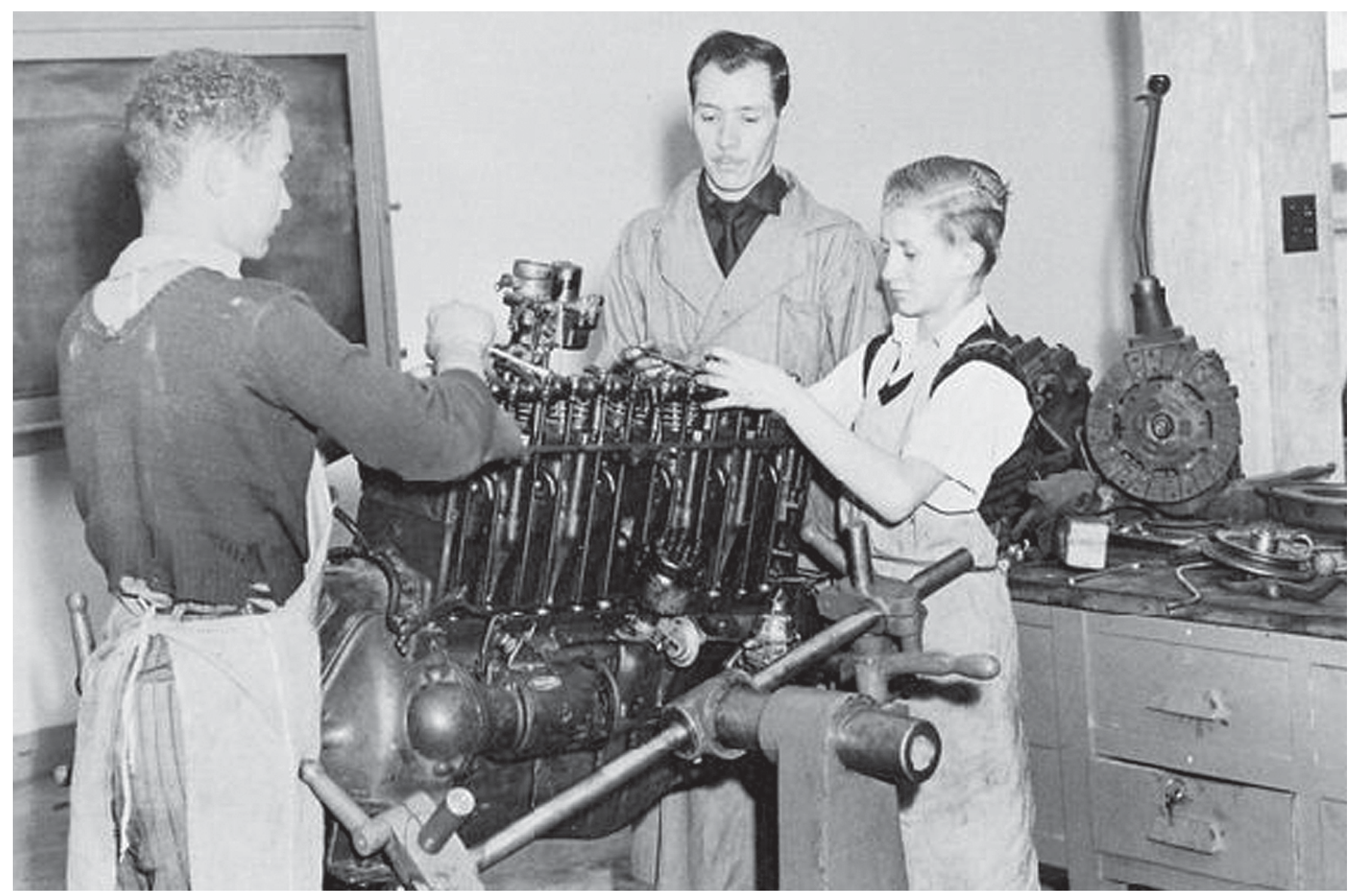

Figura 4: Oficina de mecânica, s.d. Senai-PR (Centro de Memória do Sistema Fiep)

Selecionar e adestrar aprendizes operários para os diferentes lugares da produção foi um desafio para intelectuais de vários campos do conhecimento científico. Médicos, engenheiros, educadores, administradores, psicólogos e assistentes sociais empenharam-se na tarefa de transformar aprendizes em sujeitos disciplinados e (con)formados para o trabalho, por meio de cursos planejados e executados sob a perspectiva da fábrica. Como aponta Bresciani (1986, p.16-17), esteve presente, entre os objetivos desse 'movimento científico', moralizar o trabalhador por intermédio da instrução pensada como conhe cimentos úteis, instrução essa que o disciplinasse no fazer das tarefas. 


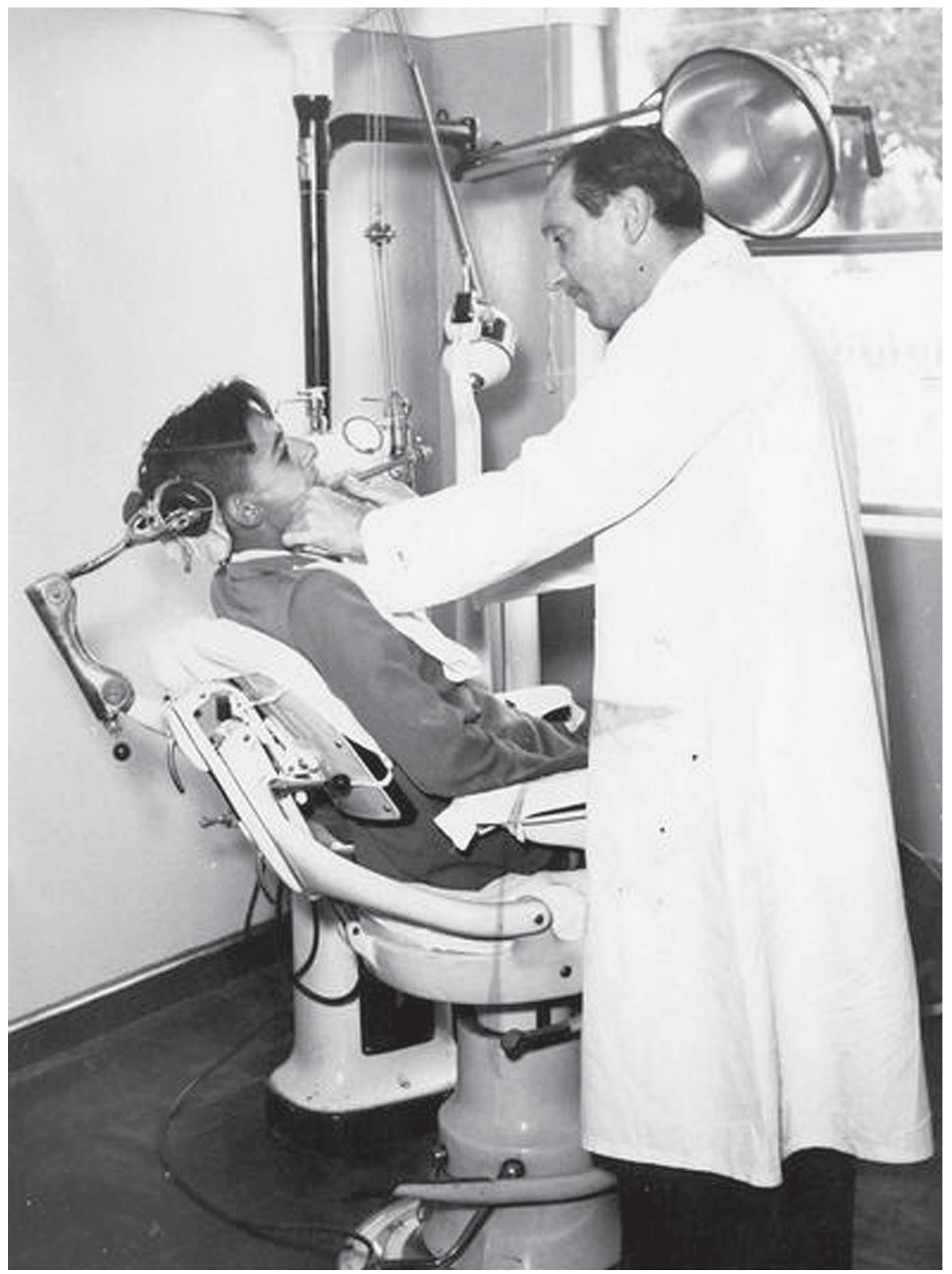

Figura 5: Consultório odontológico, 1945. Senai-PR (Centro de Memória do Sistema Fiep)

“É francamente desfavorável a impressão que em geral, causam, ao médico eao higienista, as condições de saúde dos operários menores que se candidatam aos cursos ordinários e extraordinários do SENAI ... 80\% são infestados por vermes e protozoários; $60 \%$ tem visão deficitária; encontram-se em média 13 cáries por boca, ..." (Senai, 1944-1945). Roberto Mange advertia, desde 1944, que "sem um Serviço Social especialmente destinado aos aprendizes alunos que Ihes proporcione assistência médica e dentária, alimentação e assistência social, mínima será a eficiência dos cursos de instrução profissional" (Senai, 1944, p.3). 


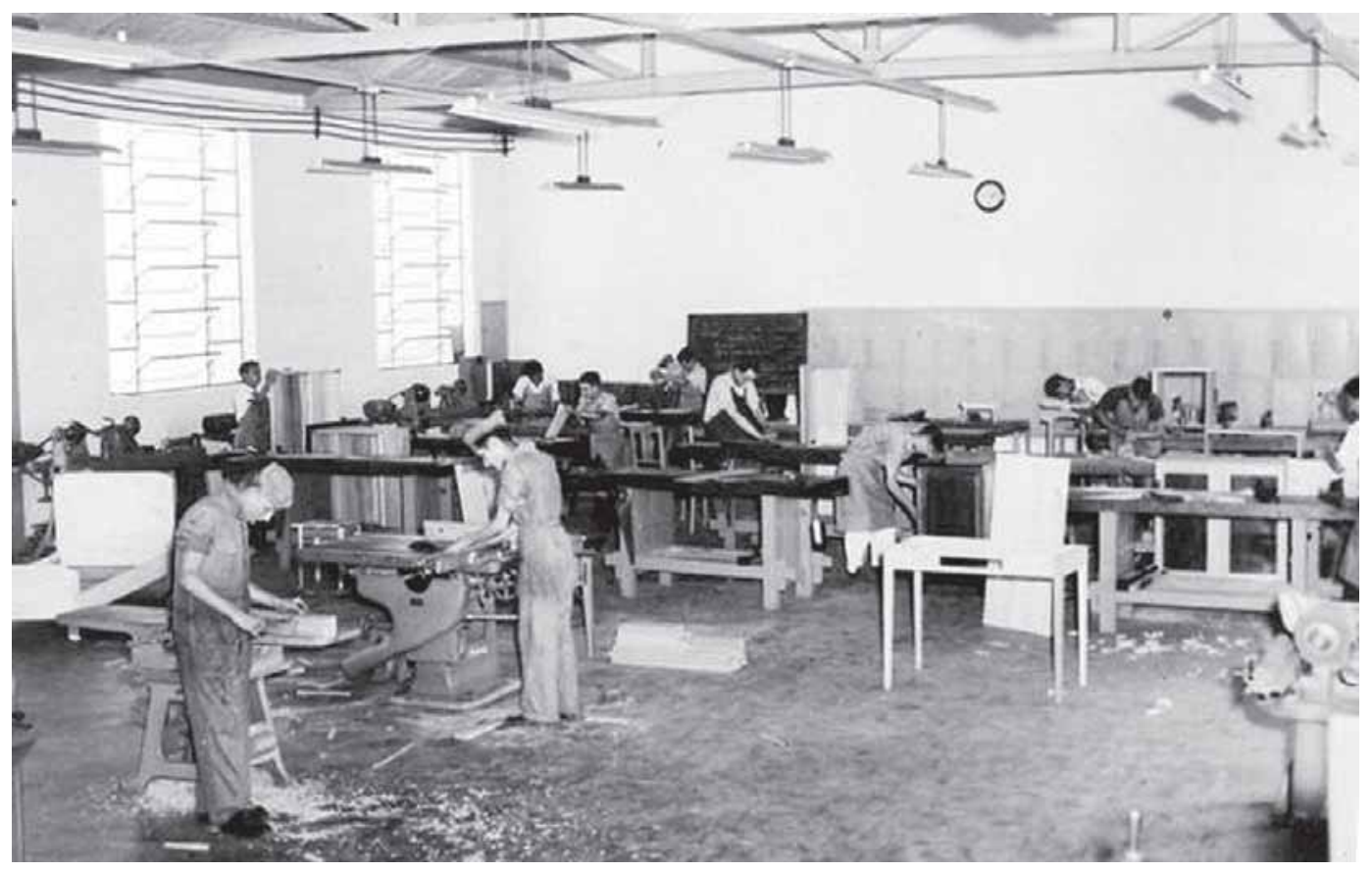

Figura 6: Oficina de serraria, s.d. Senai-PR (Centro de Memória do Sistema Fiep)

Desde a década de 1920 processos de substituição da economia extrativista se faziam notar no Paraná. Café, al godão, trigo, cevada e milho vinham mudando o perfil produtivo.

O engen ho deu lugar às torrefações, aos moinhose aos primeirossilos. No esteio dessa mudança surgem novas manufaturas ligadas ao desenvolvimento urbano, motivado pela associação da economia agrícola à indústria de transformação: cantarias, pedreiras, olarias. Dessa forma, mantém-se uma incipienteatividadeindustrial, destinada a suprir a demanda dos serviços de manutenção do maquinário - serrarias, serral herias, ferrarias, cerâmicas... (Cabas et al., 2004, p.47).

$\mathrm{Na}$ Figura 7, alunos e professores recebem autoridades em visita à Escola de Curitiba, o que proporcionava visibilidade ao projeto de formação para o trabalho. Tal como exposições mundiais ou feiras industriais, visitas aos espaços das oficinas apresentavam objetivos muito definidos: tornavam-se teatros da indústria, espetáculo que o capitalismo promovia para celebrar as gran des fábricas, "catedrais da nova humanidade" a cumprir "papel decisivo na formação de uma mentalidade técnica e na difusão de uma ideologia da Ciência e do Progresso" (Perrot, 1988, p.91).

Quanto ao fomento da mecanização e racionalização pelo Senai, no início dos anos 1950, Weinstein (2000, p.219) observava:

muitos gráficos jul gavam sua profissão ameaçada pela racionalização e pela inovação tecnológica. Não é de surpreender, pois, que as únicas queixas contra o SENAI e sua missão tenham partido do Trabalhador Gráfico. O jornal dos gráficos criticava artigos escritos por um instrutor do SENAI sobre seu ofício, e em resposta à convocação do SENAI a cursos de emergência para suprir a carência de gráficos, os editores afirmavam que a carência de gráficos não se devia à falta de formação mas aos baixos salários. 


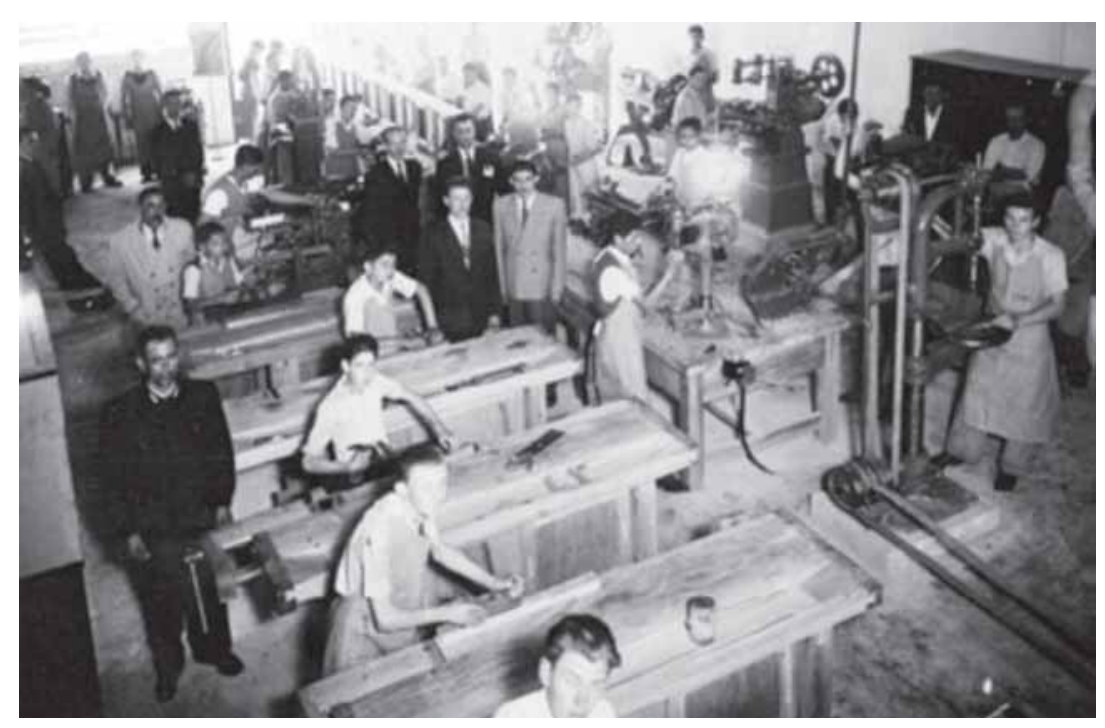

Figura 7: Oficina de marcenaria, 1950. Senai-PR (Centro de Memória do Sistema Fiep)

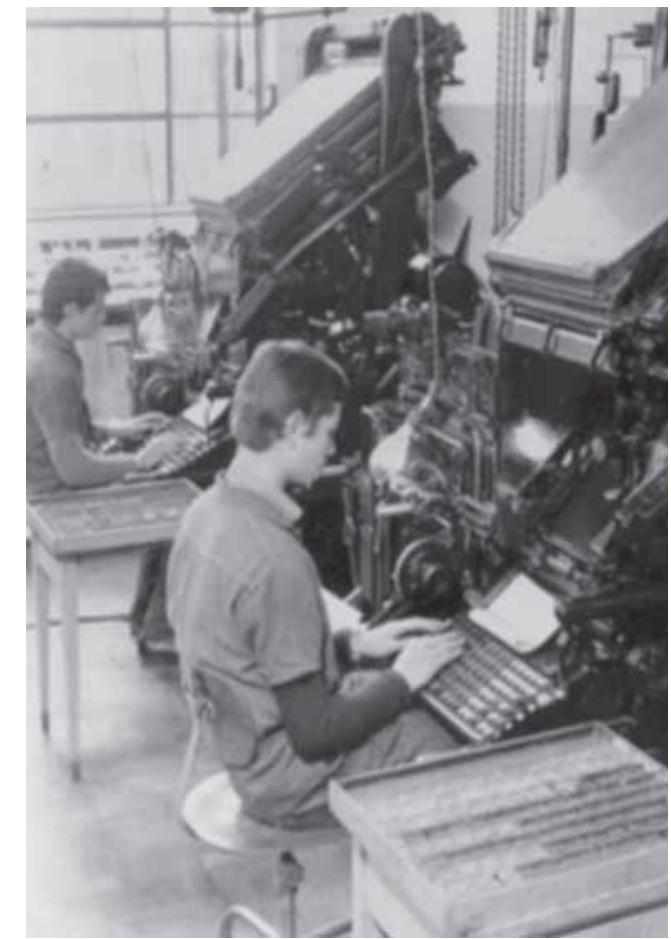

Figura 8: Oficina de artes gráficas,

1953. Senai-PR (Centro de Memória do Sistema Fiep)

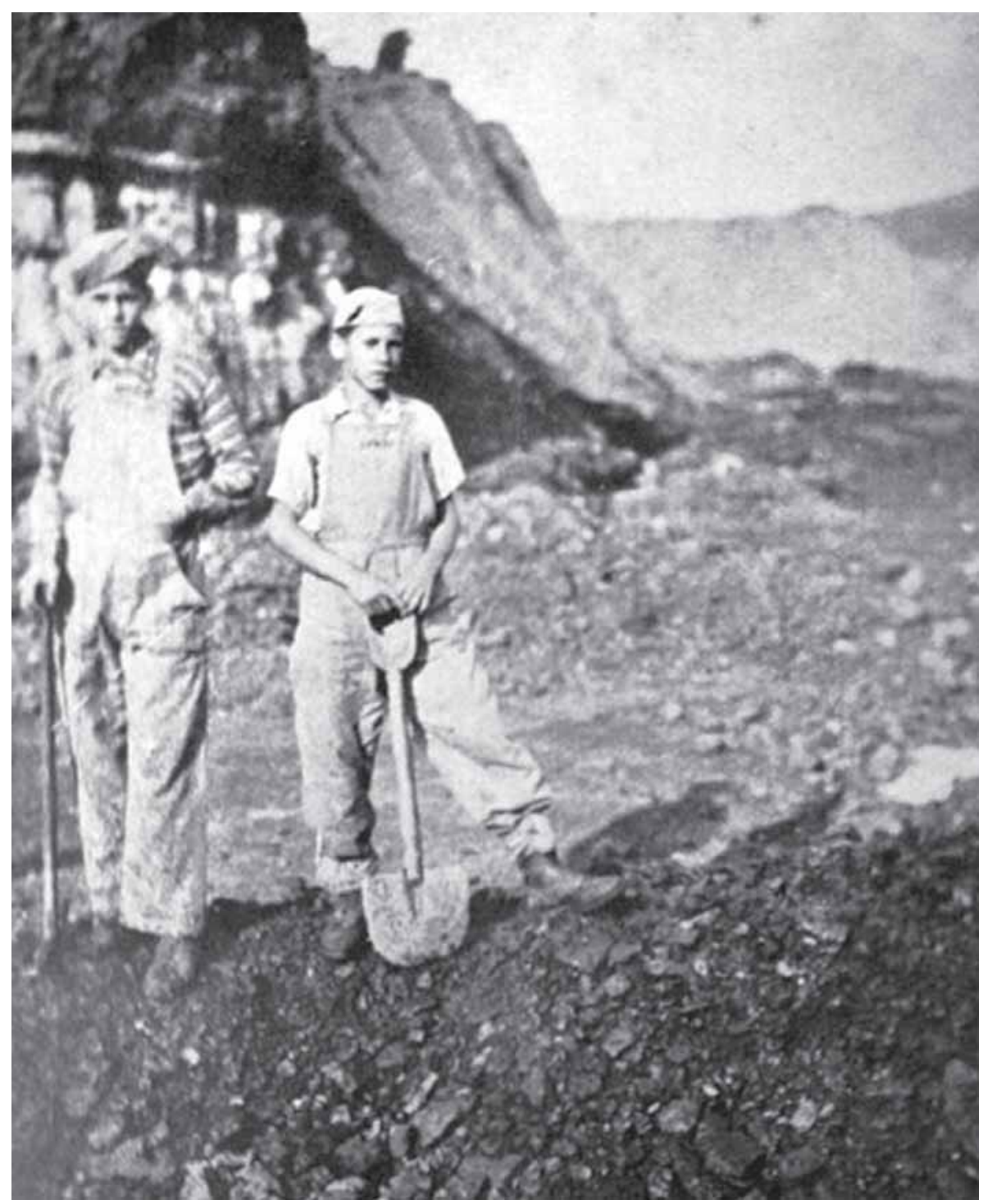

Figura 9:

Aprendizes

nas minas de

Siderópolis

(SC), 1947.

Senai-PR

(Centro de

Memória do

Sistema Fiep) 
Vera Regina Beltrão Marques, Desirê Luciane Dominschek

Em Siderópolis, zona de mineração de carvão de Santa Catarina, o Senai Regional inaugurou uma escola com vistas a formar principalmente mineiros, capazes de "permitir a racionalização dos trabalhos de mineração" (Senai, 1947), seguindo convicção da instituição e dos dirigentes da Companhia Siderúrgica Nacional, que pretendiam transformar a indústria carbonífera do estado num dos fundamentos principais da siderurgia nacional.

Acontece, porém, quea legislação trabal hista brasileira proíbe o trabal ho demenores de 21 anos em serviços de subsolo, o que não só impediria a aprendizagem como não permitiria que osapren dizes queterminassem o curso pudessem exercer a profissão abraçada. É verdade que os dirigentes do SENAI como os industriais de mineração de carvão conheciam bem o dispositivo da lei citado, mastodos esperavam quefosse aprovado pelo Congresso Nacional um projeto delei solicitado pelo Ministério do Trabalho, Indústria e Comércio, que facultaria aos menores de 18 anos formados em escolas do SENAI ou do Ministério de Educação o trabal ho nas minas. Todos esperavam essa solução porque parecia fora de dúvida que ela não só contribuiria para a organização racional dos trabal hos de mineração, como, consequentemente, importaria, na valorização do fator humano empregado nas minas. No entanto, o projeto de lei encaminhado ao Congresso por mensagem do Presidente da República, embora aprovado sem restrições pela Câmara, foi rejeitado pelo Senado, tornando-se impraticável a aprendizagem de mineração para menores. Isso alterou profundamente a estruturação da apren dizagem em Siderópolise foi necessário modificar radicalmente o plano del ineado. ... E os cursos de treinamento para minei ros passaram a atender somente al unos com mais de 21 anos dei dade (Senai, 1947).

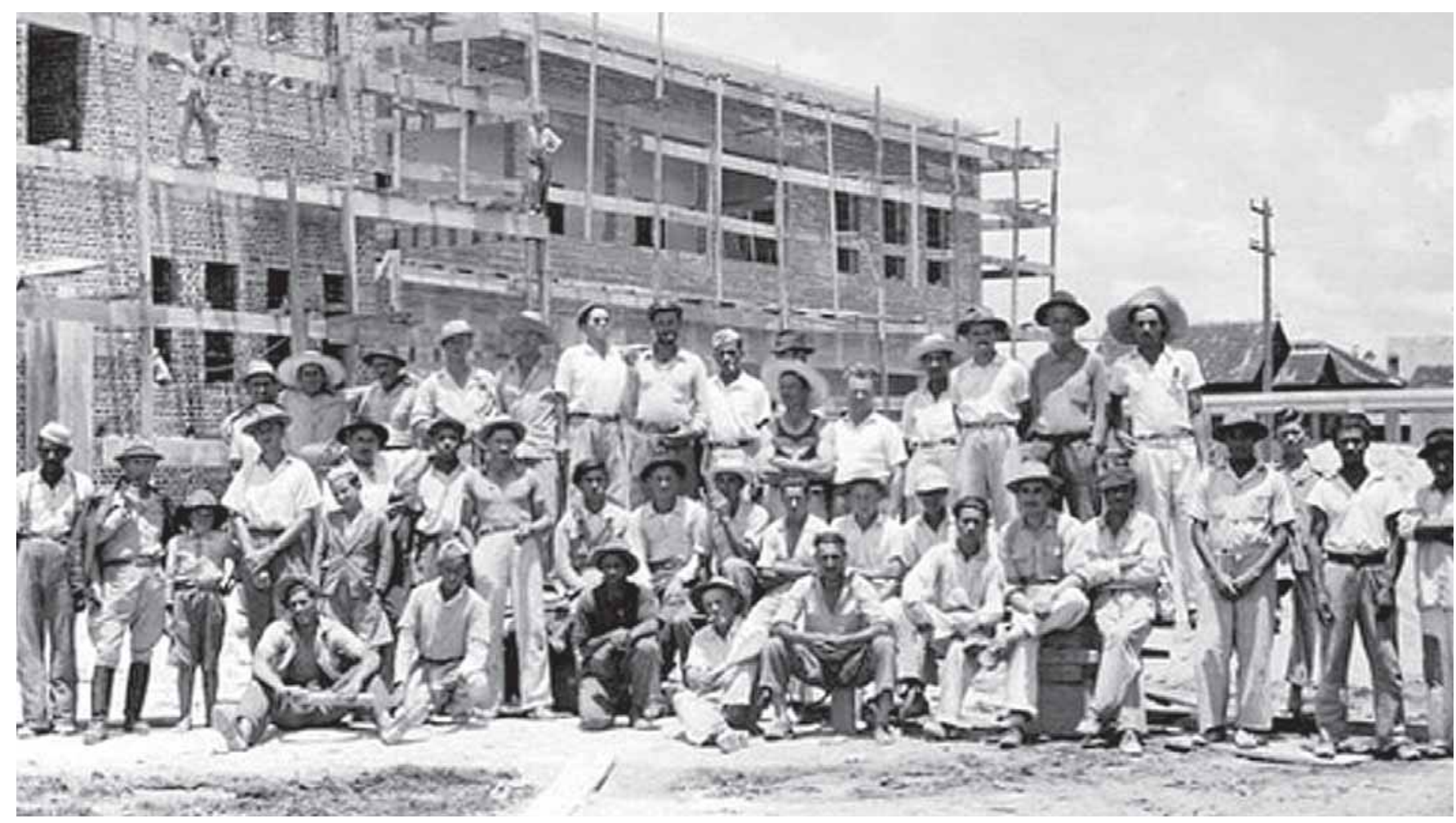

Figura 10: Vista parcial da construção da Escola, 1947. Senai-PR (Centro de Memória do Sistema Fiep) 
O Serviço Nacional de Aprendizagem Industrial - SENAI é muito bom. Na escola do SENAI a gentepode estudar e trabal har tendo o direito de escolher o ofício quesequer. Os professores são muito bons. Estuda-se, por semana, três vezes meio dia de aulas práticas, e meio dia de aulas teóricas. Os outros três dias trabal ham-se na firma. Não se paga nada e ainda se ganha todo o material que se precisa. Ganha-se um pequeno ordenado, da firma por mes eapren de-se para: alfaiate, marceneiro, el etricista, mecânico, serral heiro, tipógrafo, cal deireiro, pedrei ro, funileiro, torneiro, soldador, etc. Estuda-se matemática, ciências, desenho técnico, tecnologia, e português. Teve uma boa ideia quem criou o SENAI (O Escudo, nov. 1949).

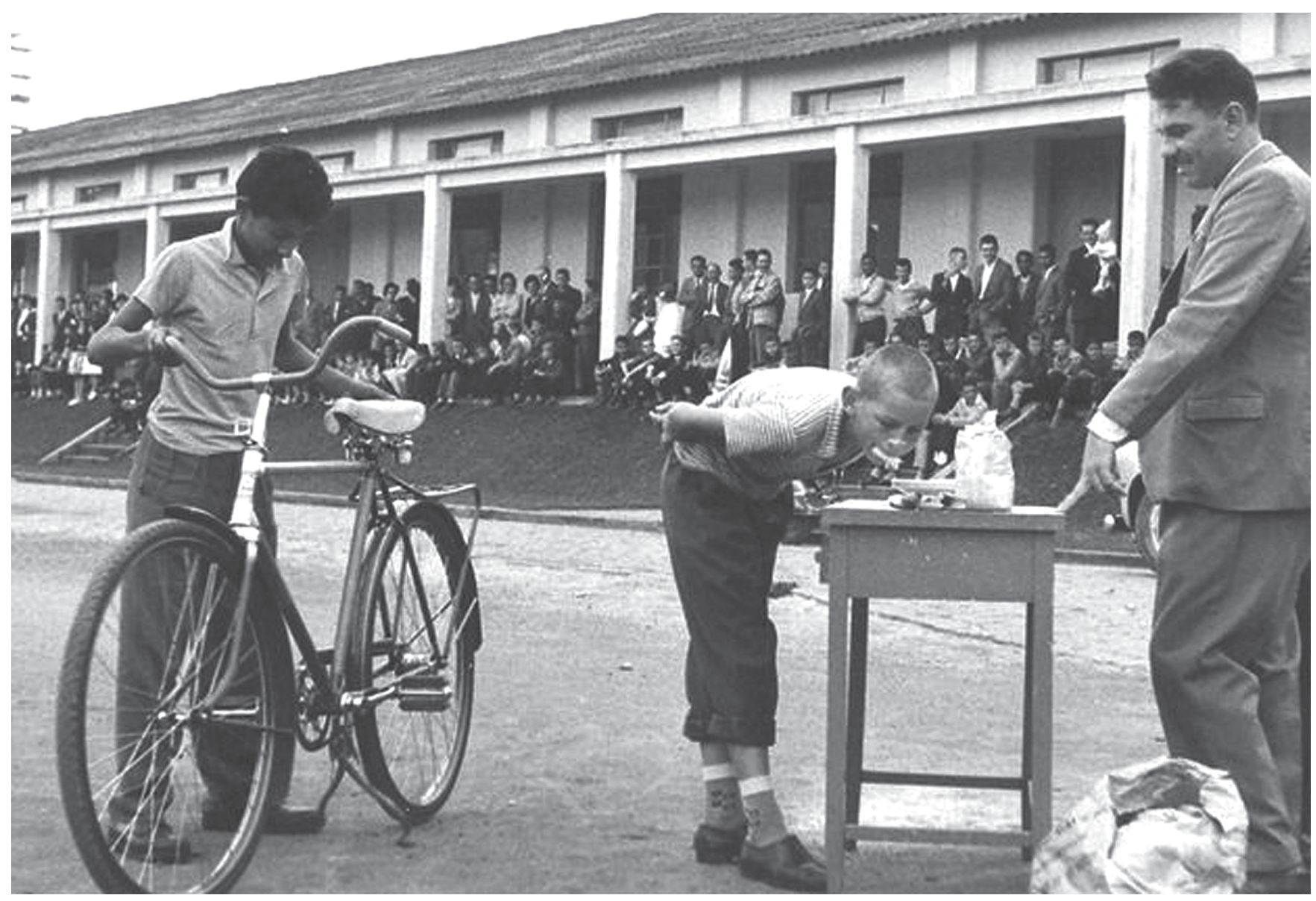

Figura 11: Festa na Escola, 1949. Senai-PR (Centro de Memória do Sistema Fiep)

No dia 1 을 de outubro foi real izada neste estabel ecimento de ensino uma festa, constou da inauguração do cinema "show" e coroação da Rainha da Escola. As 19:30h. em diante foram recepcionados os convidados econduzidos pel os alunos para o salão de cinema, o qual estava fartamente iluminado e enfeitado. As 20:00 h. foi iniciada a projeção do filme: "Três dias devida", com o artista Errol Flyn. Esta projeção durou 1:30h. Apósteve início o baile de coroação que foi animado pela orquestra 'foliões'. Transcorreu com o máximo brilhantismo a coroação da rainha (O Escudo, nov. 1949). 


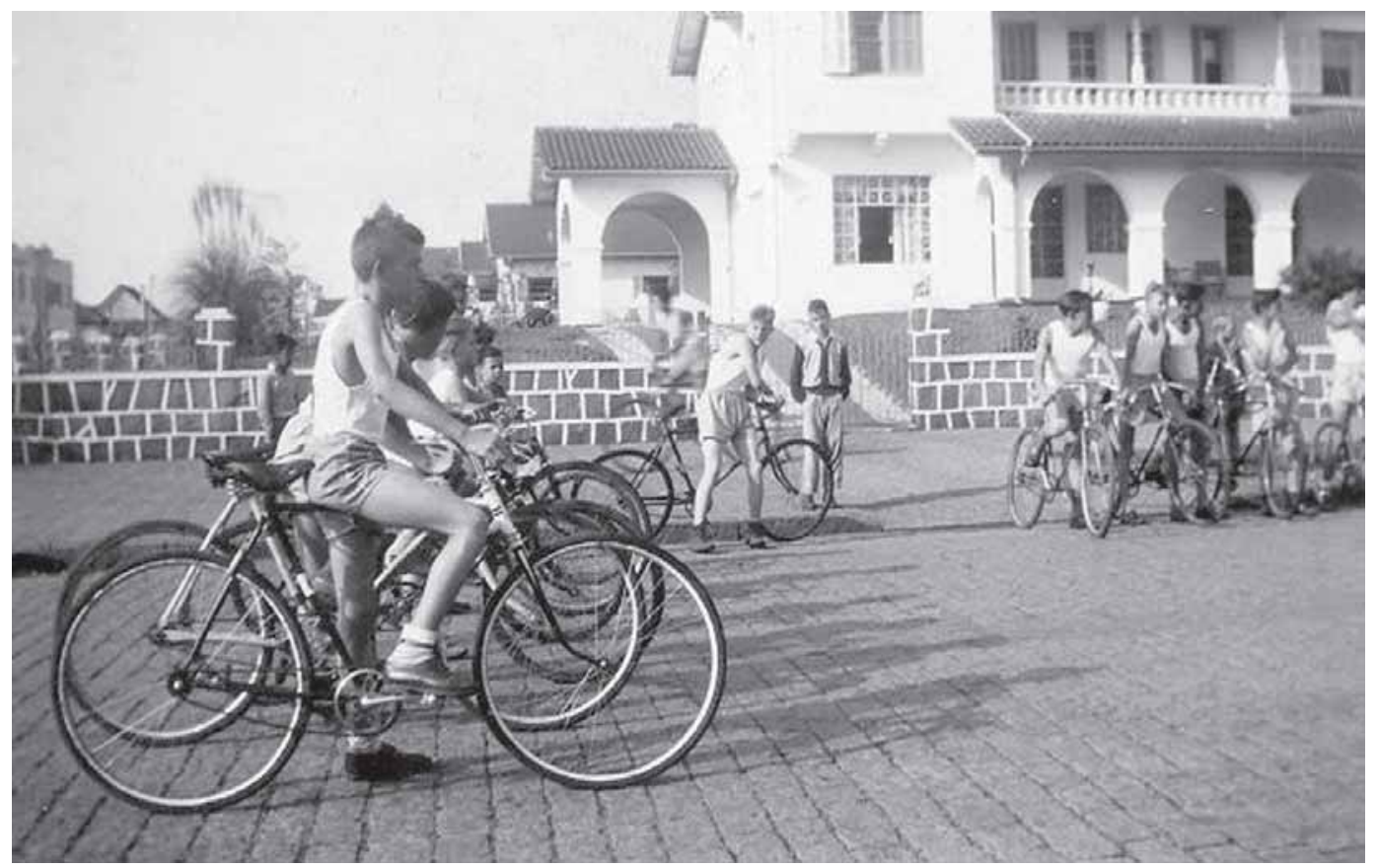

Figura 12: Torneio ciclístico em Curitiba, s.d. Senai-PR (Centro de Memória do Sistema Fiep)

A bicicl eta éo meio de transporte mais usado pela classe operária e pelas pessoas mais modestas. Hoje, com o encarecimento das passagens de ônibus, al ém das deficiências destemeio detransporte, maior éo número de pessoas que usam a bicicleta, pois com esta o horário émais garantido, evitando atraso. Além destas vantagens a bicicleta ain da serve para a prática de esporte, obrigan do a exercitar-se pessoas que trabal ham sentadas ou em serviços que não exigem esforço ou movimentação. Apesar de seu preço ter se elevado muito ul timamente, há as facilidades do crediário para sua aquisição (O Escudo, maio 1953).

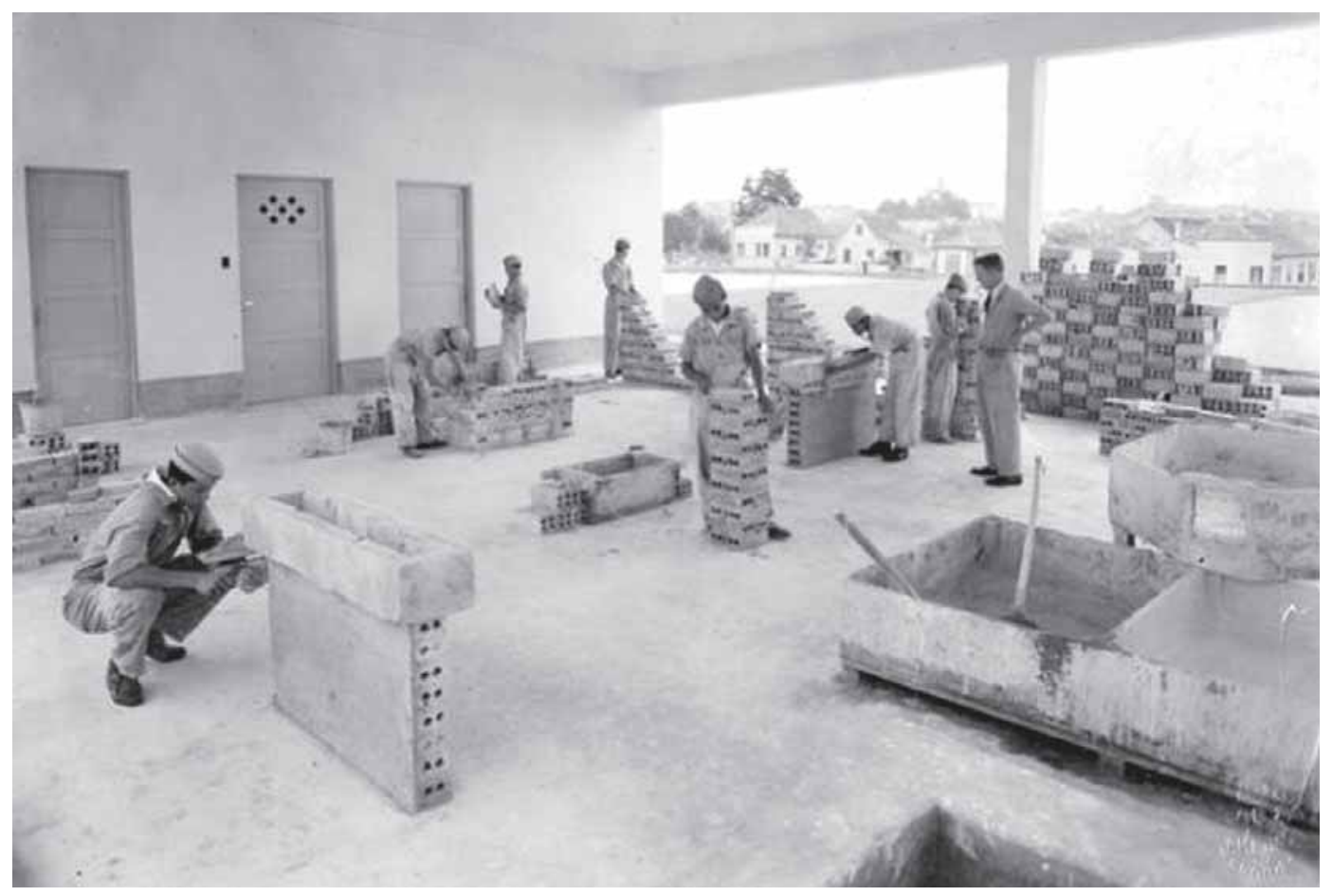

Figura 13: Curso de pedreiros, 1955. Senai-PR (Centro de Memória do Sistema Fiep) 
Eu sou trabal hador e frequento a Escola SENAI, onde estou matriculado no curso de pedreiros. Entendo bastante sobre o assentamento detijolos, pedrase já trabal ho bem com a colher. Vou indo bem com meus trabal hos, meus estudos, pois a escola SENAI, como ninguém, sabe ministrá-los. A minha profissão é boa porque mais tarde será dela que irei tirar o dinheiro para o meu sustento e poderei ganhá-lo como água. Enfim, trabal ho com a colher, o esfregador, o prumo, o nível, a régua, o bal de e a pá, sabendo também preparar a massa associada ao cimento (O Escudo, jun. 1951).

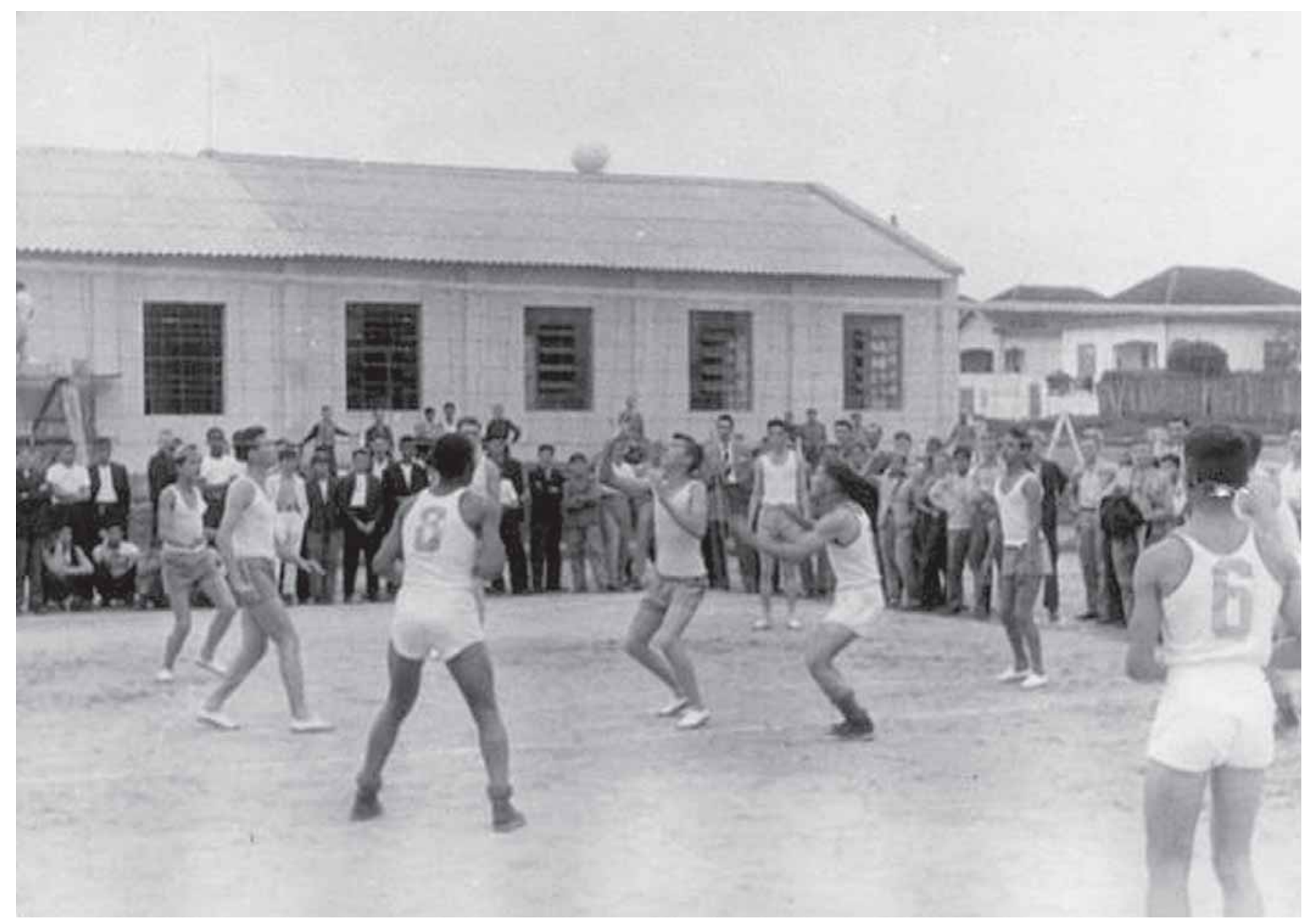

Figura 14: Jogo de vôlei dos alunos de Curitiba e Londrina, 1950. Senai-PR (Centro de Memória do Sistema Fiep)

Si m nós precisamos de competições esportivas para el evar o nome desta grande escola profissional. Senós tivéssemos dentro do SENAI agremiações tais como futebol, voleibol, poderíamosaproveitar grandes el ementos que se espal ham por dentro da escola. E porque nós alunos, professores e instrutores não nos unimos um ao outro eformamosisto que tanta falta faz aqui na escola, as agremiações esportivas? (O Escudo, set. 1949).

Gosto muito de fazer exercício físico. Desde que comecei a fazer física, passei a me desenvolver maisea mesentir mais disposto para o trabal ho. Está provado que o exercício físico adequado eo ar puro fazem do homem um ‘Hércules' (O Escudo, maio 1953). 


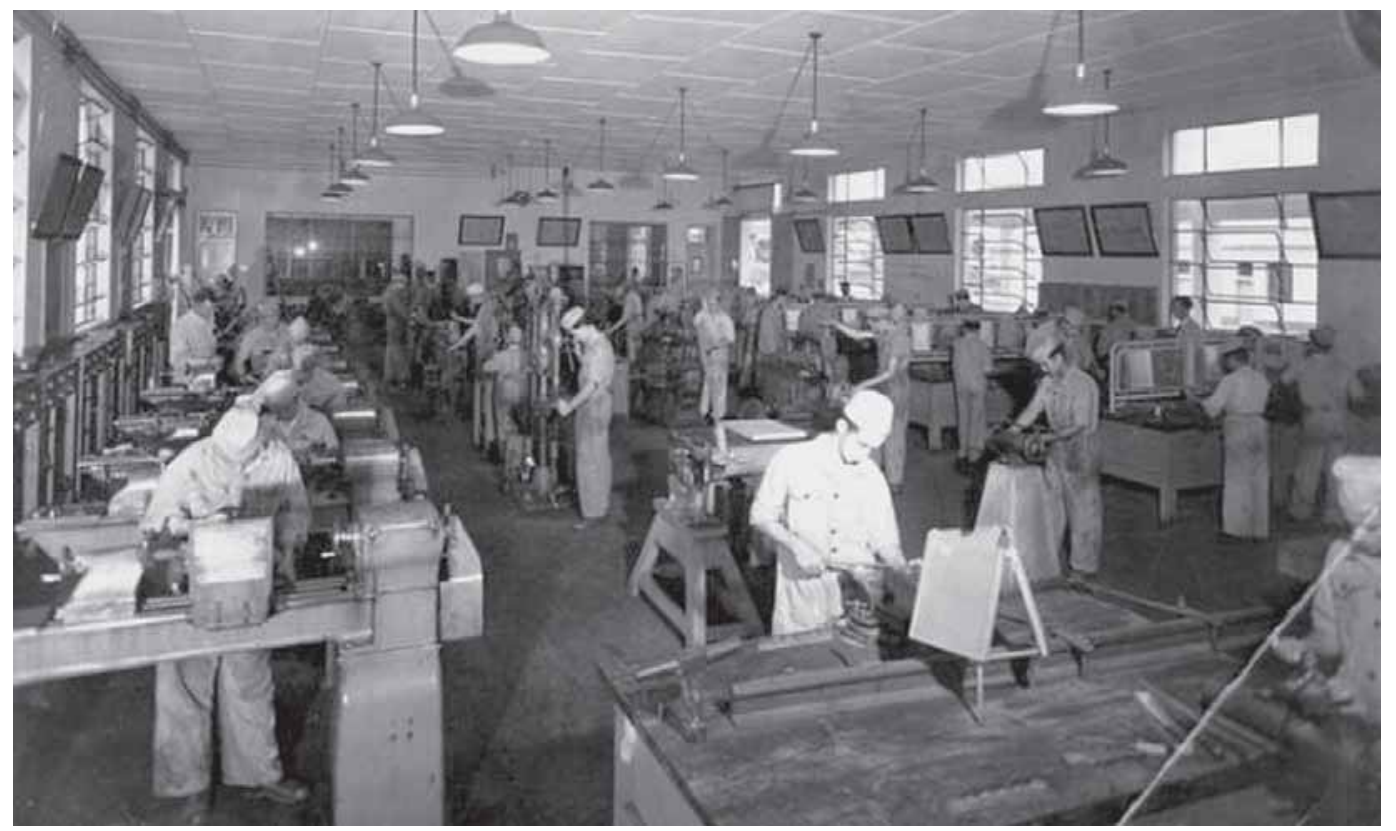

Figura 15: Oficina de tornearia mecânica, 1955. Senai-PR (Centro de Memória do Sistema Fiep)

A higieneéuma das coisas maisimportantes que o homem deveobservar com seu corpo e com seu vestuário. Do ponto de vista social econômico há vantagens em ser asseado, poisuma pessoa limpa merecemais atenção que outra desl eixada. Senuma loja entrarem duas pessoas, no mesmo momento, será atendida primeiro a que se apresentar mais decente, pois a reação normal do balconista será considerar mais quem apresenta probabilidades deser um melhor freguês. Assim também, entre dois operários candidatos à mesma vaga será escol hido o que revelar mais cuidados com sua própria pessoa, poiso futuro patrão raciocinará, normal mente, queele dispen sará também mel hores cuidados às máquinas eferramentas. Acima de todas essas consideraçõesimportantes para nós, não devemos esquecer o mais importante, isto é, os ben efíci os que a higiene traz para nossa saúde (O Escudo, set. 1949).

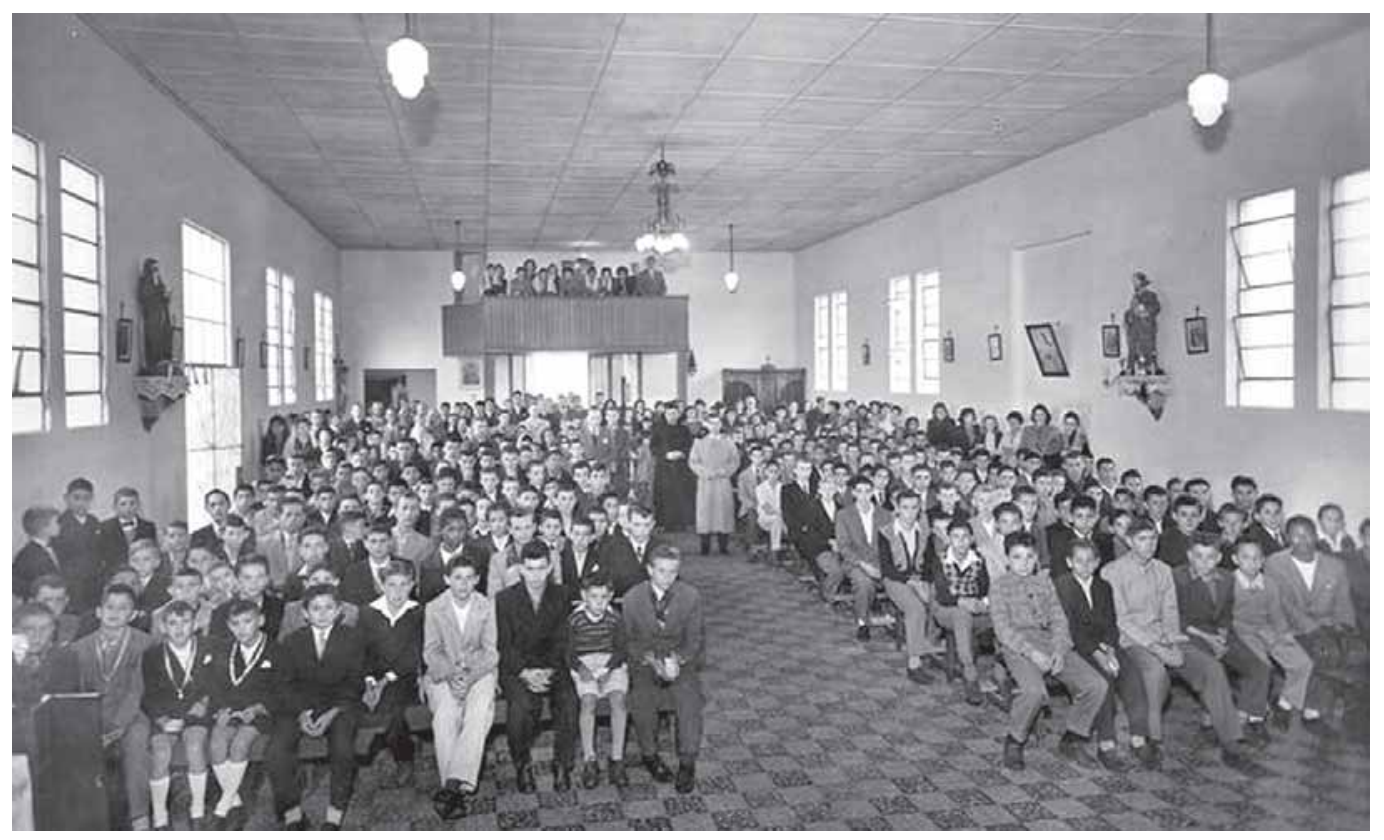

Figura 16: Celebração de Páscoa, 1956. Senai-PR (Centro de Memória do Sistema Fiep) 
Mais uma vez, solenemente, e com o concurso dos Padres da Paróquia de N.S. do Rocio, cuja I greja fica ao lado da Escola, fizemos a já tradicional Páscoa dos alunose Servidores do SENAI (O Escudo, jun. 1955).

Para nós católicos, é uma consagração a Páscoa do SENAI, realizada todos os anos. Ela revigora nossos corações. Os alunose funcionários que não têm oportunidade de confessar, de comungar, durante o ano aproveitam a Páscoa do SENAI, para cumprir essa obrigação de bom católico. Os que vão à igreja por preguiça, acabam se convencendo que é obrigação sua, dever seu ir à missa uma vez por semana (O Escudo, jun. 1955).

\section{Considerações finais}

A formação para o trabalho, na escola do Senai de Curitiba, atendia aos objetivos colocados nacionalmente pela instituição: formar trabal hadores, especialmente aprendizes de ofício para a indústria que se expandia. Imagens, relatórios e transcrições das matérias de o Escudo reforçam as premissas de uma educação em que estudo, trabalho, família, pátria, calendário cívico e religioso encontravam-se entrelaçados, buscando constituir um todo articulado. Aspectos técnicos mesclavam-se com ordem, disciplina, saúde e hierarquia. Afinal, além da preparação profissional estava em questão 'afastá-los das ruas'. Contudo, as ruas se haviam tornado palco de lutas sociais, com a mobilização da classe trabalhadora. Um rol de greves acompanhou as ações dos trabal hadores paranaenses, no decorrer do processo de industrialização, e ferroviários, ervateiros, carroceiros, sapateiros, alfaiates, estivadores, barriqueiros cruzaram os braços (Cardoso, Araújo, 1986; Araújo, Cardoso, 1992).

Também havia concepções diferentes a alimentar as propostas de formação, nas duas décadas. A inicial foi defendida por Roberto Mange, e posta em prática pelo Senai, pelo menos até sua morte, em 1955: a formação integral do aluno, do cidadão. Para o engenheiro e pedagogo, uma formação profissional completa, que bem permitisse ao indivíduo desempenhar um ofício ou uma profissão (oficiais ou profissionais), distinguia-se daquela proporcionada aos trabalhadores ensinados, aqueles treinados e tributários de uma formação parcial, de um adestramento para real izar certas operações (Zanetti, Vargas, 2007). Para formar o aprendiz cidadão, projetaram-se e criaram-se serviços médicos e sociais, porém diferentes do que se poderia chamar de assistência caritativa ou filantrópica tradicionais. De todo modo, tratava-se de serviços sociais que prestavam assistência aos alunos. Em São Paulo, por exemplo, a Inspetoria Médica logo foi substituída pelo Serviço de Higiene do Trabalho, acrescido da atribuição de fiscalizar o regime alimentar dos alunos.

Importantes mudanças ocorreram na regional do Senai-SP, a partir da morte de Mange, mas se mantiveram os serviços de assistência aos alunos no decorrer dos anos 1950. Certamente o desenvolvimento industrial de São Paulo, diversamente do que ocorria no Paraná, pode explicar parte das transformações pelas quais passaram a metodologia dos cursos e as práticas assistenciais. Mas isso ficará para outro estudo.

\section{NOTAS}

${ }^{1}$ O Senai, o Serviço Social da Indústria (Sesi), o Serviço Social do Comércio (Sesc) e o Serviço Nacional de Apren dizagem Comercial (Senac) formam o Sistema S, encarregado de ministrar formação profissional para a indústria e o comércio e promover práticas assistencialistas. O quadro organizacional do Senai 
Vera Regina Beltrão Marques, Desirê Luciane Dominschek

compõe-se em uma alçada nacional (órgão normativo, orientador e coordenador) e alçadas regionais, encarregadas da operacionalização. Formação e desenvolvimento profissional são suas atividades-fim, cabendo formar e desenvolver profissionalmente aprendizes e operários tanto nos centros de formação profissional quanto nas empresas.

2 Roberto Simonsen, industrial paulista, foi importante divulgador dos objetivos da administração científica e da organização racional do trabal ho. Nos anos 1920, apontava as máximas do taylorismo e fordismo como 'perfeito remédio' para sanar os males econômicos e sociais do Brasil via indústria racionalizada e cientificamente administrada. Embora historiadores questionem se os projetos de organização racional do trabalho na indústria paulista seguiram os princípios de Taylor e de Ford, esse é tema espinhoso, no qual não nos deteremos. Sobre taylorismo e fordismo na indústria paulista, ver Zanetti, Vargas, 2007.

${ }^{3}$ Roberto Mange, engenheiro e educador suíço, chegou em São Paulo em 1913 atendendo ao convite do empresário e engenheiro Francisco de Paula Souza, para lecionar na Escola Politécnica. Em 1923 dirigiu, no Liceu de Artes e Ofícios de São Paulo, o Curso de Mecânica Prática, que se transformou em Escola Profissional Mecânica em 1925. A partir de então passou a ocupar diversos cargos institucionais. Participou do Instituto de Organização Racional do Trabalho (Idort) e lecionou na Escola Livre de Sociologia e Política. Foi o primeiro diretor do Senai na importante Regional de São Paulo e um baluarte na defesa dos princípios da razão industrial e das ciências do trabalho.

${ }^{4}$ Álvaro Tenca (2006, p.45) diz tratar-se do "cidadão-trabalhador, que deve fazer como manda a ciência da produção".

${ }^{5}$ Sobre o tema, ver Marques, 2009.

${ }^{6}$ O boletim dos alunos, produzido pela Associação dos Alunos da Escola de Curitiba, era publicado semestralmente. Escrito e impresso pelos aprendizes, passava por correção dos professores e continha artigos sobre atividades, cursos, profissões e visitas realizadas pelos estudantes do Senai. O primeiro número foi veiculado em 1949 e o último, em 1996. Sobre O Escudo, ver Dominschek, 2008.

\section{REFERÊNCIAS}

ARAÚJO, Silvia; CARDOSO, Alcina. Jornalismo e militância operária. Curitiba: Editora da UFPR. 1992.

BRESCIANI, Maria Stella.

Lógica e dissonância, sociedade de trabalho. Revista de História, São Paulo, v.6, n.11, p.7-44. 1986.

BURKE, Peter.

Testemunha ocular: história e imagem. Bauru: EdUsc. 2004.

CABAS, Antonio et al.

Paraná, o século, o asilo. Curitiba: Edigraf. 2004.

CARDOSO, Alcina; ARAÚJO, Silvia.

1o de maio: anos de solidariedade e luta.

Curitiba: Editora da UFPR. 1986.

CIAVATTA, Maria.

O mundo do trabalho em imagens: a fotografia como fonte histórica (Rio de Janeiro, 19001930). Rio de Janeiro: DP\&A. 2002.

DE BONI, Maria Inês Mancini.

O espetáculo visto do alto: vigilância e punição em Curitiba (1890-1920). Curitiba: Aos Quatro Ventos. 1998.

DE BONI, Maria Inês Mancini.

Vigilância e punição: o espaço da criminalidade na constituição do trabalhador urbano:

Curitiba, 1890-1920. História: Questões e

Debates, Curitiba, v.8, n.14-15, p.45-99. 1987.

DOMINSCHEK, Desirê Luciane.

O Escudo: a alma do Senai-PR, 1949-1962.

Dissertação (Mestrado) - Setor de Educação,

Universidade Federal do Paraná, Curitiba. 2008.

FONSECA, Celso Sucow da.

História do ensino industrial no Brasil. Rio de Janeiro: Senai. 1986.

KARVAT, Erivan Cassiano.

A sociedade do trabalho: discursos e práticas de controle sobre a mendicância e a vadiagem em Curitiba, 1890-1933. Curitiba: Aos Quatro Ventos. 1998.

MARQUES, Vera Regina Beltrão.

A 'fabricação' de aprendizes nas escolas paulistas do SENAI (1942-1955). História da Educação, Pelotas, v.13, n.29, p.171-191. 2009.

O ESCUDO.

Curitiba, ano 7, n.13. jun. 1955.

O ESCUDO.

Curitiba, ano 5, n.9. maio 1953.

O ESCUDO.

Curitiba, ano 3, n.5. jun. 1951. 
O ESCUDO.

Curitiba, ano 1, n.2. nov. 1949.

O ESCUDO.

Curitiba, ano 1, n.1. set. 1949.

PANDINI, Silvia.

A Escola de Aprendizes Artífices do Paraná:

"viveiro de homens aptos e úteis" (1919-1928).

Dissertação (Mestrado) - Setor de Educação,

Universidade Federal do Paraná, Curitiba. 2006.

PEREIRA, Magnus R. de Mello.

Semeando iras rumo ao progresso. Curitiba: Editora da UFPR. 1996.

PERROT, Michelle.

Os excluídos da história: operários, mulheres, prisioneiros. São Paulo: Paz e Terra. 1988.

QUELUZ, Gilson Leandro.

Concepções de ensino técnico na República Velha, 1909-1930. Curitiba: Cefet-PR. 2000.

RAMOS, Arthur.

A criança-problema: a higiene mental na escola primária. 4. ed. rev. Rio de Janeiro: Livraria Editora da Casa do Estudante do Brasil. 1954.

SENAI.

Serviço Nacional de Aprendizagem Industrial. Informativo, São Paulo, n.12. out. 1946.

SENAI.

Serviço Nacional de Aprendizagem Industrial. Informativo, São Paulo, n.5. mar. 1946.
SENAI.

Serviço Nacional de Aprendizagem Industrial. Relatórios do delegado da 7ạ Região. Curitiba. Centro de Memória do Sistema FIEP-PR, série Relatórios. 1943-1947.

\section{SENAI.}

Serviço Nacional de Aprendizagem Industrial. Relatórios do diretor-geral, São Paulo. Projeto Memória, série Relatórios. 1944-1945.

\section{SENAI.}

Serviço Nacional de Aprendizagem Industrial. Relatório do diretor regional, São Paulo. Projeto Memória, série Relatórios. 1944.

TENCA, Álvaro.

Senhores dos trilhos: racionalização, trabalho e tempo livre nas narrativas de ex-alunos do Curso de Ferroviários da antiga Paulista. São Paulo: Editora Unesp. 2006.

WEINSTEIN, Bárbara.

(Re)formação da classe trabalhadora no Brasil (1920-1964). São Paulo: Cortez. 2000.

ZANETTI, Augusto; VARGAS, João Tristan. Taylorismo e fordismo na indústria paulista.

São Paulo: Humanitas. 2007.

\section{u u UUU}

